\title{
PROMOTING PEACEFUL LIFE: INTEGRATING PEACE EDUCATION THROUGH ENGLISH FOREIGN LANGUAGE CLASS
}

\author{
NUSKHAN ABID \\ STAIN Kudus, Indonesia \\ nuskhan@stainkudus.ac.id
}

\begin{abstract}
As a global language, English has an ability to promote the term of peace. The peaceful concept can be applied in English Foreign Language (EFL) class to give a better contribution to the global society. Teaching is not only concerning on shifting a theory into class participants, but also delivering the real life context on it. The aim of this paper is to promoting the social and peaceful life issued into EFL class to give a contribution for the global peace. The descriptive analysis technique was utilized for the analysis of the data collected from library and online journal article research. The analysis is showed that peaceful life is built effectively from little action like teaching and learning in class by integrating with the peaceful concept on it. As a result, it is expected that teachers can develop the EFL curriculum and material with a peaceful life concept integrated to it.
\end{abstract}

Keywords: promote, peaceful life, teaching, foreign language, integration, language teaching.

\section{Introduction}

The mass media headline showed inter-religious conflict, sectarian violence, suicide bombings, crossfire, and warfare. It is like there is no hope to build a harmony and peace in the entire world. Cates as stated in Pratama \& Yuliati $(2016$, p. 1) that our world faces serious global issues of terrorism, ethnic conflict, social inequality, and environmental destruction. We have to be able to prepare our students to deal with those problems with what so called as "Global Education". (Unesco, 1994)

English is a language which is used in every part of this universe. As a global language, it is used for communication between one country to another. Kruger $(2012$, p. 18) stated in a globalized world, social interaction is not only occurring within local networks, but increasingly within non-local networks owing to ever-improving communication technology. In order to be able to communicate effectively within non-local networks, language becomes an issue of practical importance. English has the potential to disseminate idea, knowledge or campaign about positive action. It can make relationship between language and the society.

There is no boundary to do it, because language has tumbled it and make it easier to be understood by the other people with different language and culture. English has unified the 
people in the whole world in the term of harmony and peace. It would be easy to share the peaceful term in the other people in the world. Marti (1996) stated each language expresses one of many possible human wisdoms. Languages are at once interpretations of reality, mythical and symbolic constructs, settings for rational life, expressions of community identities, territories for communication and dialogue. Languages are the most prodigious productions of human creativity. They must therefore be considered a common treasure of humanity. Each language is the heritage of the community that expresses itself in that language, but it is also the heritage of the whole of humanity.

Teaching and learning English is not only knowing about grammatical term, reading, listening, or writting, it must touch the social awareness. Teacher has responsibility to spread the social contribution to their society. Teaching is a political act and that teachers need to raise students' critical consciousness of their world. (Freire, 2013) Teacher should give not only material, but also the social values to the class participants as it becomes their responsibility to spreading good values to everyone. Human is created to give a better contributions in the world. As a social creature, human has responsibility make peaceful life. Peace and serenity is necessity since it is become a human right issue. Integrating the teaching materials with global issues like peace, freedom, human right, or environmental problems will bring class participants in to the new learning experience.

Integrating peaceful concept into EFL class will provide new meaningful content to the students. Students will get real context to improve their skill and ability. (La Luzerne-Oi \& Xiezopolski, 2006 , p. 1). Some discussion related to peaceful life and it integration in EFL class are disclosed in the further section. Peaceful life is not only a beautiful myth which is happen on the middle of nowhere. Human as a social creature has the responsibility to keep the world set in peace and harmony. Diversity is a unique term in human life. There are thousand way to build a peaceful life. One of them is through language teaching.

\section{Peace Education Concept}

As a social creature every human wishes to life without bothered and disturbed by something they do not want. The diversity in is not the main problem. Culture differences, tradition and habit is a harmony in the human life, so we must respect each other. The term of peace can be translated into two main context. First is negative peace and the second is positive peace. Galtung as stated in Friedrich (2007, p. 74) While peace may mean different things in different contexts and cultures, most scholarly discussions of peace take into concepts of negative and positive peace. Negative peace is the absence of war, a state of affairs that is sought through diplomacy and negotiation. Positive peace is achieved through the promotion of fair social conditions and structures and relies on respect for human rights, ecological concerns, education, and economic wellbeing as stated by Barash and Webel on Friedrich (2007, p. 74). The term of peace is not limited on the description above. Mutual respect is one example what we called peace in the daily life. The freedom to do worship without terror and annihilation of inter-religious conflict is the other one.

Teacher must lead their students to take a part in social responsibility action with peace education concept integrated in the class. As educator, teacher is social agency to promote and campaign about social issue, because it is the teacher responsibility. Arikan (2009, p. 88) mention socially responsible teaching (SRT) seeks ways to change classroom interaction so that students focus on (and hopefully act against) real world problems such as hunger, gender inequality, immigration issues, racism, ageism, and pollution. Reardon as cite on Arslan et al. (2015, p. 2302) defines peace education as developing reflective and contributing capacities for achieving and maintaining peace. 
Peace education is the solution to solve the violence, warfare, or sectarian conflict with educational approach. Peace education unifies the teacher and student to make a social change in their life through the friendship, smile, loves and respect each other. There is no coercion, and pressure. Once the conditions change, the peaceful life is reached. Peace education incorporates students and teachers into a process for change, contributes them to behave peace oriented, and contributes to be reconciliatory. This contribution continues permanently after peace education. Thus, this contribution makes possible atmospheres which are solution oriented, environments which result in a functional way of conflict without damage, and environments that don't have any violence elements (Arslan et al., 2015, p. 2302).

Teaching and learning peace education is supposed to introduce and explore students and teachers' knowledge about peace life. The major goal of this concept is to improve the sense of tolerance, respect and wisdom. The attitude will be formed at the time of peace education concept implemented in their daily life.

\section{Promoting Peaceful life in Class}

Teacher should not limit their concept to share with the students. The old paradigm on teaching always makes the teacher as a sovereign in giving the material to the students. They give a material which printed on the textbook. There is no contextual example from the environment. Students cannot explore the real life context to integrating with their English skill. This method of teaching focuses on teacher and relieves the students change to be independent. Integrating real life context such as peace, global issues, or human right will create the students-centered more effective. As stated by La Luzerne-Oi \& Xiezopolski (2006) global issues lend themselves to creation of effective student-centered activities such as role-plays, simulations, surveys, debates, and group projects.

Autonomous learner is offered by teacher for the students when peaceful life concept integrated in teaching and learning material. Students will get the various option to choose the suitable activities in teaching and learning process. Peaceful life is ones of global issue which can be integrating into teaching materials. Global education encourages learner autonomy by offering a wide range of topics for students to learn about. More importantly, central to global education is that people participate in the world and make their own choices rather than only following their leaders. Projects invite students to choose, as they work in less teacher-controlled settings and have some freedom on what topics or sub-topics they choose as well as what shape their projects take. (K. A. Cates \& Jacobs, 2006, p. 173)

Teaching and promoting the term of peace in EFL class are the teacher responsibility. As an educator this is the best way to give a contribution to the environment. Every human has to keep harmony and peace for the better world. Language is the one to promote the peace. Teacher must change the mindset of the student majority about learning is only to gain the good score in national final test. The benefit of learning is to give a better contribution in to the society. Teacher should introduce the concept of peace in their teaching and learning process. Teaching is not only concerning on shifting a theory into class participants, but also can delivered the real life context on it. Classroom is the place where peace and peaceful life campaign begun. Students are expected to implement the concept to their society.

EFL teachers should not focus on the grammatical term. They must integrate the main material with social issues, peace, or the relevant context. The material must be suitable with teacher(s) objective and the students needed. So the aim of the teaching will be reached. Harsono (2015, p. 169) stated that by having the objectives of the teaching/learning or being familiar with the needs of the learners, the teachers can develop their own materials for the learners to achieve the objectives or to fulfill the needs of the learners. 
In the other word Cates (K. Cates, 1990, p. 44) EFL instructors around the world integrate global issues and global education into their teaching in a variety of ways that involve language-teaching content, methods, materials, course design, teacher training, and extracurricular activities. Teacher must create his own environment, textbook, material and syllabi and combine with peace education concept. Students will get the different experience and the knowledge of peace, and it is expected that they can implement this concept in their daily life.

\section{Methods of Teaching}

Peace education's teaching and learning process is similar with the other teaching and learning activities. Teacher shares the material to students, guiding them, and handle the class. The way how the teacher teaches their students is the substantial thing to be prepared first before take an action. The method used by teacher will elevate the student motivation. It must be suited with the learning objective and needs. The method used in teaching and learning process is based on the teacher independency. Teacher is free to create and combine the teaching method such as role play, game or discussion. The method chosen for teaching language must facilitate the students-centered teaching and contain peace education concept.

The material, discussion, simulations or the activities is intended to give a portrait of peaceful life, harmony, diversity and respect to each other. It is expected to raise students responsive in the global issue like war, peace, conflict, or violence. In addition, the students can give the solutions to the social problem they faced to create the better and peaceful life.

\section{Integrating Peace Education concept to EFL Material}

Peaceful education is unfamiliar concept for teacher. This is a something new in the field of teaching and learning. Teaching and learning EFL is focused on four skill; listening, speaking, reading, and writing. Teacher usually uses standard textbook from the Ministry of Education, but the content and the material is far away from peace education concept. Teacher can create their own textbook in the line of peaceful life theme. There are millions of free internet resources related with this topic is ready to use. Teachers need to be more creative to prepare the material before share to their students.

Language teaching can be contextualized in all of field. Since language became a tools for communication, everyone can share the idea, culture and knowledge through English. This pedagogy would encourage intercultural understanding and critical thinking about aspects of local and world cultures. It will facilitate the dissemination and the critical acquisition of linguistic and cultural knowledge through English (Guilherme, 2007). Arikan (2009) state the connection between peace education and foreign language teaching can be found in these newer forms of theory and practice of foreign language teaching because foreign language teaching has started to scrutinize individuals' place in their social and natural environments.

Teacher can contextualized the EFL material from the environment and our society. Teacher should choose one of theme that correlates with the material discussed. Teacher will be easy to creating their peace concept material for teaching and learning in EFL class. Pearse as cited in Arikan (2009) define context as 'what surrounds something' and use the example of 'it is hard' meaning either 'it is difficult' or 'it is rigid', according to the context of the sentence. Efe et al. as cited in Akdemir et al. (2012, p. 3968) describes authentic materials as those educational materials which can be used to teach authentic and natural knowledge, competences and abilities. Those materials do not need to be developed or prepared for the purpose of educational.

Integrating the contextual event into EFL material can be collect from selected news in daily newspaper. Teacher chooses the news which contains peaceful life, peace, or the concept of harmony. Teacher can adapt it and use in speaking section, reading section, writing section or 
analyzing the grammar section. It is easy for teacher to collect and integrate the material from the environment. The authentic material can be used to teach the finest knowledge, competence and ability. Students will learn how to face the crucial situation and they will know how to solve it from the discussion section. Students not only get the EFL material but they also get the new experience about how to apply their EFL into real life. It will improve their motivation to learn more about English.

The other important things for teacher to do is keep the material in context and aligned with the students cultural and nationality (Akdemir et al., 2012). Teacher instructional material should contextualize and it needed by students. The instructional techniques hold an important role to motivate and activate learners, the instructional materials play the role to contextualize the language usage and to meet language learners' needs, instructional media bring the teaching into real life situation, the teachers facilitate and ease the learning process, the learners manifest and produce meaningful and appropriate utterances as an indicator of the instructional success, and the speaking components relates to which components of the speaking to be the emphasis in a speaking class activities (Manurung, 2015, p. 44). Otherwise Kruger (2012, p. 22) If TESOL is concerned with providing learners with the necessary skills to communicate successfully with others, introducing aspects of peace education into the curriculum could promote peaceful communication. The successful of peace education and promoting the peaceful life rely on teacher and the students.

The integration between English as a Foreign Language material with contextual material such as peace, warfare, or social theme will make students feels like in the real situation. They will get the emotion, the condition and they will learn something besides the structural sentence, vocabulary or academic writing. Promoting peaceful life concept through the integration of peace education at EFL class brought a new experience and learn from the other perspective. So it will sharpen the student sensitivity.

\section{Conclusion}

Teaching and learning English as Foreign Language (EFL) is not only shifting theory of English itself. Since English has become an international language, everyone can communicate each other without disturbed by errors or misunderstanding in communication. Teacher can integrate the content of EFL material and contextualized it with the situation happen surrounding us. English can disseminate the term of peace into the whole world. The chaos situation, conflict and warfare is our responsibility to overcome it. Teacher should not only teach the term of grammar or how to speak fluently, but he has the social responsibility and makes a better society.

Teacher must integrate the peace education concept into EFL material. It is expected to produce the golden generation who is not only good in academic subject, but also has the social sensitivity and try to campaign the peaceful life for the better future. English language teaching can be adapted in various materials. It can be adapted for the special purposes like campaign and promoting the peaceful life. The social issue taken by teacher will give the new learning experience for the student, and they will have attention to global peace campaign. 


\section{References}

Akdemir, A. S., Barin, M., \& Demiroz, H. (2012). Broadsheet English: Teaching Speaking Through Newspaper Articles. Procedia - Social and Behavioral Sciences, 46, 3967-3971. http://doi.org/10.1016/j.sbspro.2012.06.180

Arikan, A. (2009). Environmental peace education in foreign language learners' English grammar lessons. Journal of Peace Education, 6(1), 87-99. http://doi. org/10.1080/17400200802655064

Arslan, Y., Günçavdı, G., \& Polat, S. (2015). The Impact of Peace Education Programme at University on University Students' Intercultural Sensitivity. Procedia - Social and Behavioral Sciences, 174, 2301-2307. http://doi.org/10.1016/j.sbspro.2015.01.891

Cates, K. (1990). Teaching for a better world: Global issues in language education. The Language Teacher, 14(5), 3-5.

Cates, K. A., \& Jacobs, G. (2006). Global issues projects in the English language classroom. In Project-based second and foreign language education: Past, present, and future (pp. 167-180). Greenwich, CN: Information Age Publishing. Retrieved from https://www. academia.edu/3547747/Global_issues_projects_in_the_English_language_classroom

Freire, P. (2013). Education for Critical Consciousness. Bloomsbury Publishing.

Friedrich, P. (2007). English for peace: toward a framework of Peace Sociolinguistics. World Englishes, 26(1), 72-83.

Guilherme, M. (2007). English as a Global Language and Education for Cosmopolitan Citizenship. Language and Intercultural Communication, 7(1), 72-90. http://doi. org/10.2167/laic184.0

Harsono, Y. M. (2015). DEVELOPING LEARNING MATERIALS FOR SPECIFIC PURPOSES. TEFLIN Journal - A Publication on the Teaching and Learning of English, 18(2), 169-179. http://doi.org/10.15639/teflinjournal.v18i2/169-179

Kruger, F. (2012). The role of TESOL in educating for peace. Journal of Peace Education, 9(1), 17-30. http://doi.org/10.1080/17400201.2011.623769

La Luzerne-Oi, S., \& Xiezopolski, I. (2006). Teaching Global Issues in the English Language Class. TESL Reporter, 39(1), 59-65.

Manurung, K. (2015). Improving the Speaking Skill Using Reading Contextual Internet-based Instructional Materials in an EFL Class in Indonesia. Procedia - Social and Behavioral Sciences, 176, 44-51. http://doi.org/10.1016/j.sbspro.2015.01.442

Marti, F. (1996). Language Education for World Peace. Retrieved July 2, 2016, from http://gilesig. org/25Marti.htm

Pratama, H., \& Yuliati. (2016). Global Education in English Classroom: Integrating Global Issues into English Language Teaching. International Journal of Social Science and Humanity, 6(9), 719-722. http://doi.org/10.18178/ijssh.2016.6.9.739

Unesco. (1994). Recommendation Concerning Education for International Understanding, Cooperation and Peace and Education Relating to Human Rights and Fundamental Freedoms. Paris: Unesco. 